\title{
THE POTENTIAL OF DIATOMS, OSTRACODS AND OTHER INDICATORS FOR HOLOCENE PALAEOCLIMATE RESEARCH IN SOUTHERN SPANISH SALT LAKES
}

\author{
J.M. Reed \\ E.C.R.C., University College London, 26 Bedford Way, London WCIH ()AP, UK** \\ "Presently at: Department of Geography, Loughborough University, Loughborough. Leicestershire LEI I 3TU, UK.
}

Keywords: Holocene. palaeolimnology, salt lakes, climate change. diatoms, ostracods, Spain.

Palabras clave: Holoceno, paleolimnologia, lagos salados, cambio climático, diatomeas, ostrácodos, Espaiia

\begin{abstract}
Although the sediment records of closed-basin saline lakes can be sources of excellent palaeoclimate data, the palaeolimnological potential of Spanish salt lakes has only recently begun to be explored. A survey of the Holocene sediment records from ten lakes in Andalucía, southern Spain, and a crater lake in Ciudad Real, central Spain, is described, based on diatoms, ostracods and other potential proxy indicators for climate change. The preservation of different indicators varies between sites. In four of the eleven sites it was either not possible to obtain a long sediment record, or useful palaeolimnological remains were not preserved. Of the remaining seven, three preserve a diatom record. Most sites contain high quality ostracod records, along with molluscs, plant macrofossils, charophyte oospores, charcoal and potentially useful mineralogical or geochemical data, and a cluster of lakes in Sevilla and Cádiz are identified which would provide ample scope for a regional study. The high quality of palaeoecological records in southern Spanish salt lakes probably reflects their more permanent character in comparison with other parts of Spain. These lakes contain evidence for significant fluctuations in limnological conditions and potentially the first strong evidence for Holocene climate change in this region.
\end{abstract}

\section{INTRODUCTION}

It is now generally accepted that palaeolimnological studies of closed-basin saline lakes in arid and semi-arid regions can be an important source of high resolution palaeoclimate data. Lake levels and salinity respond to changes in effective moisture, and these fluctuations can be recorded by numerous biological, mineralogical and geochemical proxy indicators preserved in sediment cores (e.g. GASSE et ul., 1987). The range of biological remains includes diatoms, calcareous microfossils (ostracods, foraminifera), plant macrofossils and invertebrates. Diatoms and ostracods are abundant, diverse and highly sensitive to salinity (GASSE. 1987; DE DECKKER \& FORESTER, 1988), and they have been a mainstay of palaeolimnology in saline lake regions of the World (e.g. FRITZ et al., 1994; GASSE et al., 1987).

In the context of palaeoclimate research, the Iberian Peninsula occupies a crucial geographical location intermediate between Atlantic and tropical climate zones to the north and south (FONT TULLOT, 1983). Until recently Holocene palaeoecological research was limited largely to pollen analysis of mountain and coastal sequences, with an emphasis more on the effects of human impact (MENÉNDEZ AMOR \& FLORSCHUTZ, 1961, 1964; DUPRE et al., 1988; STEVENSON \& HARRISON, 1992; RIERA-MORA \& ESTEBAN-AMAT, 1994). Although evidence for Holocene climate change is suggested by documentary references (FONT TULLOT, 1988), the prevailing view was of a gellelal increase in humidity with the onset of the Holocene, but little significant change thereafter (e.g. HUNTLEY \& PRENTICE, 1988).

This was probably due in part to the lack of sensitivity of these sites, or to the overwhelming influence of human activities such as forest clearance on the terrestrial palaeoecological record. Evidence for fluctuations in Holocene climate has started to emerge from research in other disciplines or in different types of environment, such as on the geomorphology of northeastern Spain (BURILLO MOZOTA et $a l$. 1986) or the morphometry of ancient olive charcoal from archaeological sites in arid eastern Spain (TERRAL \& ARNOLD-SIMARD, 1996). 
Some of the most convincing evidence has emerged recently from palaeolimnological research on saline lakes. The Iberian Peninsula is the only region of western Europe where the climate is sufficiently arid for the formation of salt lakes. A catalogue compiled by PARDO (1948) listed 240 saline lakes, although many have since disappeared through drainage or ploughing, or been altered by the input of fresh water or urban waste (MONTES \& MARTINO, 1987). There is an extensive body of literature on their modern ecology, limnology and conservation status, starting with the work of Margalef over fifty years ago (e.g. MARGALEF, 1947), but their palaeolimnological potential had not begun to be explored until a few years ago. Comin and colleagues have investigated the mineralogy and geochemistry of a sediment sequence from the Laguna dc Gallocanta, Teruel, northeastern Spain (COMIN et al., 1990), and Stevenson, Davis and colleagues have carried out detailed and well-dated palynological research into the Holocene vegetation history of several saline lakes in the Ebro Basin, northeastern Spain (STEVENSON et al., 1991; MACKLIN et al., 1994; DAVIS, 1994). Of most relevance to this study, DAVIS (1994) extended the study to the reconstruction of past lake levels using palaeolimnological data derived mainly from plant macrofossil and mineralogical analyses, and presents evidence for significant climate change over the past 9,300 years.

The potential for diatom- or ostracod-based research has yet to be explored, and many salt lakes have never been cored. To begin to address this issue, this paper describes a detailed survey of the quality of the Holocene palaeolimnological record of Spanish salt lakes in the Guadalquivir depression (Andalucia, southwestern Spain) wherein the emphasis is on diatoms and ostracods. The study follows previous work (REED, 1995 and in press a) which suggests that this region probably contains the lakes of the highest potential for such research, since diatoms are poorly-preserved in sediment cores from saline lakes in other parts of Spain. In addition to diatoms and ostracods, the survey encompasses plant macrofossils, molluscs and charophyte oospores as sources of additional data. A detailed lithostratigraphic description allows the further assessment of the potential for mineralogical analyses. Finally, macrofossil charcoal content can be an indicator of the degree of natural or human-induced burnillg.

\section{THE STUDY REGION}

The distribution and origins of Spanish salt lakes are described in detail by COMIN \& ALONSO (1988) and MONTES \& MARTINO (1987). Their main distribution is in areas of flat or gently undulating topography in the Ebro Basin of northeastern Spain, the Guadalquivir Basin of Andalucia. southern Spain, and to the south of the large central plateau in the interior known as La Mancha. A smaller cluster is also found to the north of La Mancha. The climate of the Iberian Peninsula as a whole is variable, due to the combined influence of Atlantic, continental and subtropical weather systems. In addition, the varied relief and the rainshadow effect of the mountains which virtually surround the interior cause a marked contrast between mountain and lowland and between coastal and interior climate regimes (DE TERAN et al., 1978). In general, the climate of the saline lake regions is semi-arid Mediterranean, with cool winters and long, hot summers, and an extended deficit in the water balance during the summer months (FONT TULLOT, 1983). In Andalucia, the openness of the region to the Atlantic allows penetration of moist airstreams in winter, spring and autumn, and mean annual precipitation in the Guadalquivir Basin is $300-800 \mathrm{~mm}$ per annum. Effective moisture is low over much of the Basin, since winters are mild (mean January temperatures $>6^{\circ} \mathrm{C}$ ) and summers very hot. The lower and middle Guadalquivir, where potential evapotranspiration is at a maximum for the Peninsula, is the hottest region of Spain and August daily temperatures often exceed $40^{\circ} \mathrm{C}$.

The origins of most saline lakes are related to processes of dissolution and subsidence of underlying Tertiary or Triassic limestone or gypsiferous evaporites. Those of La Mancha and the Ebro depression tend to be very shallow ephemeral lakes ( $<1 \mathrm{~m}$ maximum depth) which dry out every summer. Deeper, permanent and semi-permanent systems up to around $10 \mathrm{~m}$ deep are more common in Andalucia. Shallow hypersaline lakes occur in most zones which may he termed semipermanent since the formation of a salt crust in summer prevents evaporation to dryness. In addition to a number of closed-basin lakes formed by tectonic processes, a cluster of small crater lakes (surface area $<0 . \mathrm{I} \mathrm{km}^{2}$ ) in central Spain are notable exceptions to this generalization.

The topography of the Guadalquivir Basin is more variable than other salt lake regions. The depression extends around $300 \mathrm{~km}$ inland from the southwest tip of Spain at ca. 20-460 m a.s.l.; it is bounded to the east and south by the Cordillera Bética, to the north by a major fault of the Sierra Morena. and is open to the Atlantic. It was once a gulf connecting the Atlantic with the Mediterranean, formed after subsidence and a major marine transgression during the Miocene. Uplift of the western Peninsula took place at the end of the Pliocene and overall marine regression followed during the Plcistocene (SILJESTRÖM et al., 1994). Thick, finegrained marine 
evaporites are preserved, and older strata such as Triassic Keuper marls outcrop in the interior. As a result of the marine influence, the majority of saline lakes are chloride dominated.

\section{SELECTION AND DESCRIPTION OF THE STUDY SITES}

In a previous paper, diatom preservation in the recent sediment record was investigated for a data-set of 59 short cores from salt lakes throughout Spain (REED, in press a). The results showed clearly that diatoms are better preserved in permanent and semi-permanent lakes of medium to low salinity. Some of these are artificially-maintained, or are karstic springs or sinkholes with major subterranean aquifer flow which would not be suitable for a palaeoecological study since lake levels, and therefore salinity, are not very sensitive to changes in effective moisture. Most of the saline lakes of the Ebro Basin and La Mancha are shallow and ephemeral and dry out every summer. In these regions, diatoms were completely absent from the recent sediment record of all ephemeral lakes sampled (24 sites) and from foul out of five semi-permanent lakes. A group of lakes with the highest potential for a study of recent climate change (decadal to century timescale) was identified, and these are without exception restricted to southern Spain.

This cannot be assumed to be a direct indicator of the quality of the Holocene fossil diatom record, since the character of the lakes, and their diatom preservation potential, may have been different in the past due to climate change and also since many have been affected recently by human activities (MONTES \& MARTINO, 1987). As noted, the potential of lakes in the Ebro Basin for Holocene palaeoclimate analysis has already been established for remains other than diatoms and calcareous microfossils by DAVIS (1994) who showed that, in addition to pollen, the Holocene sediment records of ephemeral lakes contain phases wherein plant macrofossils, charophyte oospores and Cladocera ephippia are well-preserved and can provide valuable palaeoclimate data.

The results of a preliminary study of Holocene sequences from lakes in central and northeastern Spain suggest that these are indeed of little value for diatom-based palaeoclimate reconstruction, (REED, 1995). Diatom preservation was assessed in nine long cores (up to $3.5 \mathrm{~m}$ depth) from lakes to the south of La Mancha and in the Ebro Basin. These comprised four ephemeral lakes, one semi-permanent hypersaline lake, and four permanent lakes or reservoirs whose water levels are currently artificially high. Diatoms were absent throughout the sequences of the first five lakes, and in the lower levels of artificially-maintained lakes. Since the majority of other lakes in these regions are similar in character and origins, and were ephemeral even prior to modern water management practises (PARDO, 1948), it can be concluded that salt lakes of these regions as a whole are probably of low potential at least in respect to diatom analysis.

Emphasis is therefore given to the lakes of the Guadalquivir Basin, Andalucia. The distribution of the coring locations is

TABLE I. Summary of site location details. selected limnological characteristics. depth of sediment cores collected in Summer, 1992. and recent human impact. for the eleven sampling sites in the study.

TABLA I. Resumen de la localización geográfica, algunas caracteristicas limnológicas, profundidad de las muestras del sedimento recogidas en el verano de 1992 . y el irnpacto de actividades antropológicas recientes, para las once lagunas analizadas.

\begin{tabular}{|c|c|c|c|c|c|c|c|c|c|}
\hline $\begin{array}{l}\text { SITE } \\
\text { CODE }\end{array}$ & LAKE & $\begin{array}{l}\text { LOCATION } \\
(N, W)\end{array}$ & $\begin{array}{l}\text { ALTIT. } \\
\text { (m a.s.l.) }\end{array}$ & $\begin{array}{l}\text { MEAN } \\
\text { AREA } \\
\left(\mathrm{km}^{2}\right)\end{array}$ & PERMANENCE & $\begin{array}{l}\text { WATER } \\
\text { DEPTH } \\
(\mathrm{m})\end{array}$ & $\begin{array}{l}\text { COND. } \\
\left(\mathrm{mS} \mathrm{cm}^{-1}\right)^{*}\end{array}$ & $\begin{array}{l}\text { CORE } \\
\text { DEPTH } \\
(\mathrm{m})\end{array}$ & $\begin{array}{l}\text { RECENT HUMAN } \\
\text { IMPACT ON WATER } \\
\text { LEVELS }\end{array}$ \\
\hline $\begin{array}{l}\text { AAMA } \\
\text { ASBL } \\
\text { BGDE } \\
\text { CALC } \\
\text { CARJ } \\
\text { CTRJ } \\
\text { CZRR } \\
\text { DDUL } \\
\text { DMDN }\end{array}$ & $\begin{array}{l}\text { L. Amarga, Lucena, Córdoba } \\
\text { El Salobral, Luque, Córdoba } \\
\text { L. Grande, Archidona, Málaga } \\
\text { L. de la Alcaparrosa, Utrera, Sevilla } \\
\text { L. de Arjona, Utrera, Sevilla } \\
\text { L. del Taraje, Las Cabezas, Sevilla } \\
\text { L. de Zarracatin, Utrera, Sevilla } \\
\text { L. Dulce, Espera, Cádiz } \\
\text { L. de Medina, Jerez, Cadiz }\end{array}$ & $\begin{array}{l}37^{\circ} 29^{\prime}, 4^{\circ} 42^{\prime} \\
37^{\circ} 35^{\prime}, 4^{\circ} 12^{\prime} \\
37^{\circ} 06^{\prime}, 4^{\circ} 18^{\prime} \\
37^{\circ} 03^{\prime}, 5^{\circ} 49^{\prime} \\
37^{\circ} 02^{\prime}, 5^{\circ} 49^{\prime} \\
36^{\circ} 55^{\prime}, 5^{\circ} 54^{\prime} \\
37^{\circ} 02^{\prime}, 5^{\circ} 48^{\prime} \\
36^{\circ} 52^{\prime}, 5^{\circ} 52^{\prime} \\
36^{\circ} 37^{\prime}, 6^{\circ} 03^{\prime}\end{array}$ & $\begin{array}{c}380 \\
420 \\
800 \\
20 \\
40 \\
130 \\
50 \\
110 \\
35\end{array}$ & $\begin{array}{l}0.04 \\
0.48 \\
0.12 \\
0.05 \\
0.02 \\
0.03 \\
0.55 \\
0.09 \\
1.40\end{array}$ & $\begin{array}{l}\text { permanent } \\
\text { ephemeral } \\
\text { permanent } \\
\text { semi-perm } \\
\text { semi-perm } \\
\text { semi-perm } \\
\text { semi-perm } \\
\text { semi-perm } \\
\text { semi-perm }\end{array}$ & $\begin{array}{c}2.5 \\
0.5 \\
8.2 \\
0.6 \\
0.6 \\
1.6 \\
\text { negligible } \\
1.3 \\
0.7\end{array}$ & $\begin{aligned} 14.0 & \\
0.4 & (33) \\
5.0 & \\
12.0 & \\
18.0 & \\
7.6 & \\
- & (338) \\
9.2 & \\
15.7 & \end{aligned}$ & $\begin{array}{l}3.33 \\
6.87 \\
2.83 \\
1.80 \\
2.00 \\
1.37 \\
5.00 \\
3.80 \\
7.50\end{array}$ & $\begin{array}{l}\text { erosion from ploughing } \\
\text { water pump on shore } \\
\text { irrigation input } \\
\text { irrigation input } \\
\text { water pump on shore }\end{array}$ \\
\hline DTLL & L. de los Tollos, Jerez, Cadiz & $36^{\circ} 51^{\prime}, 6^{\circ} 01^{\prime}$ & 70 & 0.71 & ephemeral & dry & (36) & 4.00 & $\begin{array}{l}\text { irrigation } \\
\text { recent desiccation } \\
\text { (formerlypermanent) }\end{array}$ \\
\hline EFTL & L. de Fuentillejo, Ciudad Real & $38^{\circ} 56^{\prime}, 4^{\circ} 03^{\prime}$ & 640 & 0.05 & ephemeral & dry & $(4.6)$ & 7.50 & recent desiccation \\
\hline
\end{tabular}

*Altit. = Altitude; Cond. = Conductivity. To give an indication of mean lake-water conductivity, additional measured values are quoted in parentheses for El Salobral and dry lakes from an earlier field season, Spring, 1992. The salinity of El Salobral in Summer. 1992 was unusually low; it a an ephemeral, mesosaline lake which had filled with fresh water following a rain storm in July, 1992 (Nature Reserve guard, pers. comm.). Data on recent human impact, which has caused a recent lowering in lake levels $\mathrm{m}$ all 1987: Fernández Palacios, 1990; Junta de Andalucía, 1991). 
shown in Figure I, and summary site descriptions are given in Table I. The list includes those sites identified in REED (in press a) as preserving diatoms in the recent sediment record, and having suitable characteristics for a palaeoclimate study. With the exception of the Laguna Grande, which is something of an outlier at an altitude of $800 \mathrm{~m}$ a.s.h in the foothills of the Sierra Nevada, the sites are located in relatively close proximity to each other, to provide the basis for a regional study wherein correlation of lake-level records would indicate the influence of regional climate change over that of local hydrological effects. They are all small (mean surface area $0.02-1.40 \mathrm{~km}^{2}$ ) and the majority are semi-permanent lakes less than $2 \mathrm{~m}$ deep which only dry out in years of severe drought.

An ephemeral crater lake outside this region, the Laguna de Fuentillejo, is also included since these systems are often exceptionally sensitive to climate change, with their small, well-defined catchments and simple patterns of groundwater flow (DE DECKKER \& FORESTER, 1988).

\section{METHODS}

Sediment cores were collected in Summer, 1992 (1-18 July) from the deepest water of lakes, or from the centre of dry lakebeds, using a hand-held echo sounder to measure water depth at the sampling site where necessary. A modified Livingstone lightweight piston corer (LIVINGSTONE, 1955) and Glew gravity corer (GLEW, 1991) were used for soft surface sediments. For deeper sediments, and for coring from dry lake beds, a Livingstone corer and Cobra percussion corer with I $\mathrm{m}$ gouge attachment were used, depending on whether the sediments were soft or hard respectively, or the Hiller corer when these were not available. Livingstone cores were extruded into plastic drainpipe and wrapped in plastic film for storage. Following lithostratigraphic description, modified Livingstone cores, Glew cores and Cobra cores were extruded in the field at $1 \mathrm{~cm}, 1 \mathrm{~cm}$ and $2 \mathrm{~cm}$ intervals, respectively.

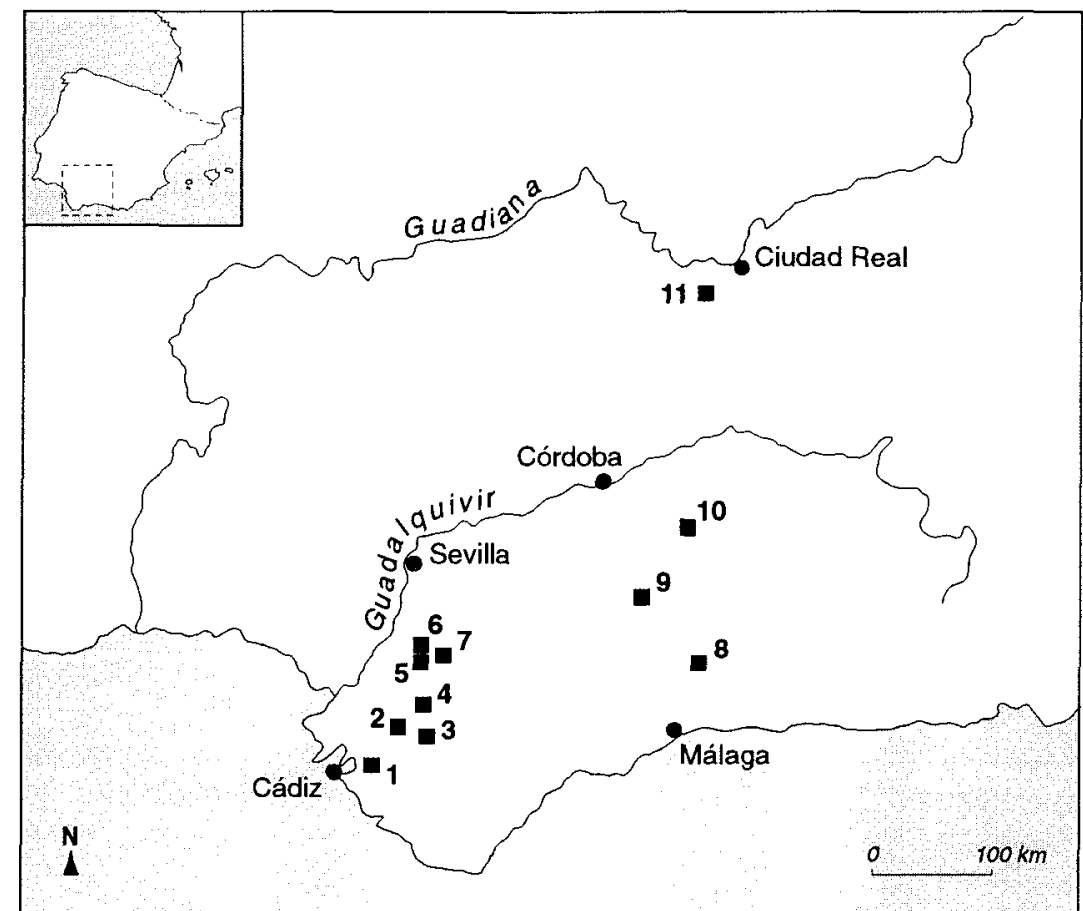

1. L. de Medina, Cadiz

2. L. de Los Tollos, Cadiz

3. L. Dulce, Espera, Cadiz

4. L. del Taraje, Sevilla

5. L. de Arjona, Sevilla

6. L. de la Alcaparrosa, Sevilla
7. L. de Zarracatin, Sevilla

8. L. Grande, Malaga

9. L. Amarga, Cordoba

10. El Salobral, Cordoba

11. L. de Fuentillejo, Ciudad Real
FIGURE I. Map showing the distribution of sam pling sites.

FIGURA 1. Mapa de la distribución de las lagunas muestreadas. 
Cores were stored in the laboratory at $4^{\circ} \mathrm{C}$. Sediment texture and composition were described using the Troels-Smith system (AABY \& BERGLUND, 1986) modified and simplified to incorporate gypsum as an element. The matrix was described as clay, silty clay or marly clay within which gypsum bands (> ca. $40 \%$ gypsum) were distinguished as a separate unit. Colour was described using Munsell Soil Colour Charts.

Core sections were subsampled for diatom analysis at 10-50 $\mathrm{cm}$ intervals depending on the core length $(50 \mathrm{~cm}$ intervals for cores $>5 \mathrm{~m}$ long) with additional samples in units of high stratigraphic variability. Slides were prepared using standard techniques (BATTARBEE, 1986), using hydrogen peroxide and hydrochloric acid for removal of organics and carbonates, and Naphrax as a slide mountant. A 5-point abundance scale was used for rapid assessment of diatom preservation, ranging from 5 = Very Abundant ('full' preservation with fragile taxa preserved and no sign of significant dissolution), $4=$ Abundant (partially dissolved but countable assemblages dominated by robust taxa most resistant to dissolution), 3 = Occasional (1-2 robust taxa dominant at too low a frequency for a count of 500 valves), $2=$ Rare (dissolved fragments) and $1=$ Nil.

For ostracods, molluscs, plant macrofossils, charophyte oospores and charcoal, ca. 10-20 g wet weight of sediment, equivalent to a ca. $1 \mathrm{~cm}$ core slice, was weighed and subsampled for wet sieving. To disaggregate flocculated clays without damaging organic remains or biogenic carbonates, subsarnples were weighed and placed in $100 \mathrm{ml} 3 \% \mathrm{H}_{2} \mathrm{O}_{2}$ for 1.5 hours. They were wet sieved over a nest of sieves $(300 \mathrm{pm}$, $180 \mathrm{pm}$ and $125 \mu \mathrm{m}$ ); the fraction less than $125 \mathrm{pm}$ was discarded and other fractions stored in alcohol prior to sorting.

For a rapid but detailed description of sediment composition, gypsum abundance was estimated on a 5-point scale in the initial stratigraphic description and the relative proportions of different gypsum crystals (prismatic, lenticular and aggregate) were described from sieved subsamples. Mollusc and seed abundance was expressed as number per $10 \mathrm{~g}$ wet weight. Broken shells were counted if the upper whorls only were missing. The abundance of charophyte oospores and ostracods was estimated per fraction and expressed on a fivepoint scale related to the approximate abundance per gramme wet weight. Ostracod valves were counted when more than half the shell was present; their abundance was underestimated since clay pelletisation obscured small valves, but sufficed for an estimate of relative abundance. Charcoal was estimated on a 5-point scale without quantification. The stratigraphy was plotted using TILIA 2.1 and TILIAGRAPH 1.21 (E. Grimm).

\section{RESULTS}

The biostratigraphy and lithostratigraphy of each sediment sequence is described belown and the relevant keys are given in Figure 2.

\section{I . Laguna de Medina, Jerez, Cádiz [DMDN]}

A $7.50 \mathrm{~m}$ core was collected from $0.7 \mathrm{~m}$ of water using the Cobra and Livingstone corers. Sediments were still soft at the base. The stratigraphy is presented in Figure 3.

The lithology was highly valiable in organic content and gypsum abundance from the core base to ca. $400 \mathrm{~cm}$ depth, above which a transition occurred to homogeneous silty clay low in organics. Diatom preservation was variable from the core-base to $460 \mathrm{~cm}$, and at the surface, and they were otherwise absent. The planktonic, salt-tolerant diatom. Cyclotella choctawharcheeana, was abundant in the midsequence of the lower core, whilst other diatom samples were dominated by benthic, salt-tolerant taxa such as Campylodiscus clypeus and Mastogloia braunii. Ostracods were abundant through most of the sequence; a major shift in species composition occurred at ca. $600 \mathrm{~cm}$ from relatively diverse assemblages dominated by Cyprideis torosa, to virtually monospecific assemblages of Plesiocypridopsis newtoni above. Molluscs and charophyte oospores were present throughout; molluscs reached peak abundance in levels below $450 \mathrm{~cm}$ where charophytes were least abundant. Plant macrofossils occurred at low abundance and were predominantly aquatics, and charcoal was present below $300 \mathrm{~cm}$.

\section{Laguna de los Tollos, Jerez, Cádiz [DTLL]}

A $4.00 \mathrm{~m}$ core was collected from the dry lake-bed of this lake which was formerly permanent but has been recently desiccated, using the Hiller corer. The stratigraphy is presented in Figure 4.

The sediments were homogeneous, calcareous silty clay which varied mainly in hardness and was low in organic content. Abundant, dissolved diatoms were preserved from $340-180 \mathrm{~cm}$ depth; they were absent in the upper sediment and very rare at the base. The base of the diatom sequence was dominated by Amphora, Mastogloia and Nitzschia spp, above which a marked shift occurred to dominance by $C$, choctawhatcheeana. Ostracod preservation coincided with that of diatoms (ca. $350-140 \mathrm{~cm}$ depth) and they were most abundant where molluscs and charophytes were also preserved. Very few organic remains were preserved above $140 \mathrm{~cm}$. At $140 \mathrm{~cm}$, ostracod species composition shifted from dominance by Cyprideis torosa and Eucypris mareotica below, to Plesiocypridopsis newtoni above. No plant macrofossils were found and charcoal was abundant only at the surface. 


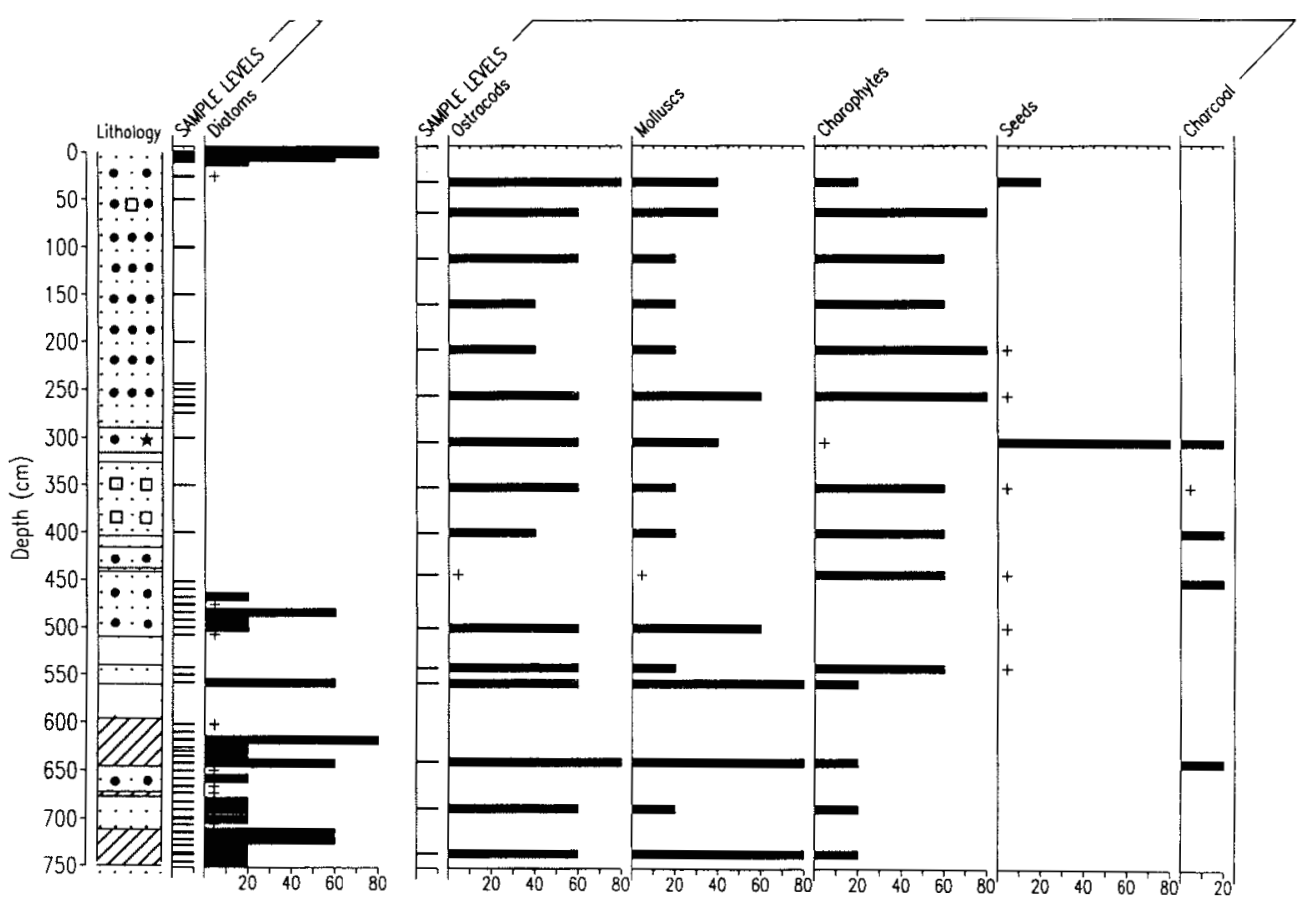

FIGURE 3. Stratigraphy of the Laguna de Medina. Jere, Cádiz. FIGURA 3. Estratigrafia de la Laguna de Medina. Jerez. Cádiz.

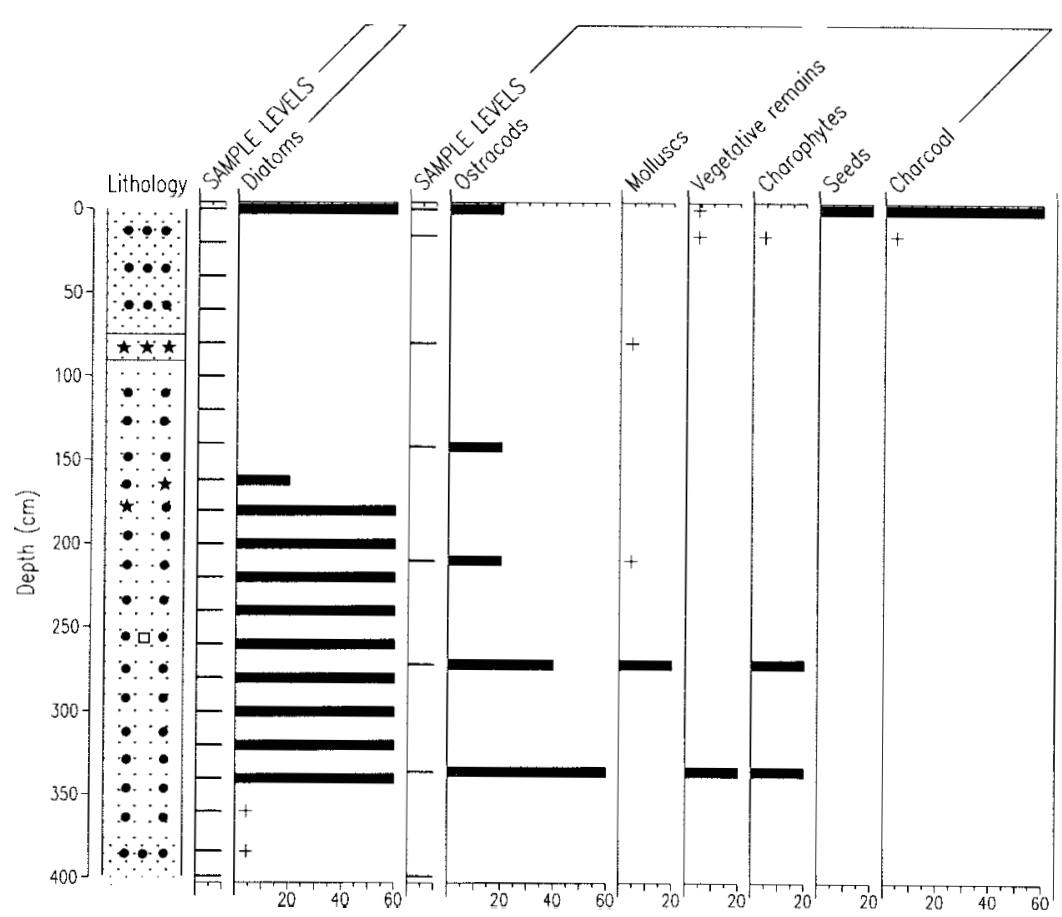

FIGURE 4 Stratigraphy of the Laguna de los Tollos, Jerez, Cádiz FIGURA 4. Estratigrafia de la Laguna de los Tollos, Jerez, Cádliz 


\section{Laguna Dulce, Espera, Cádiz [DDUL]}

A $3.80 \mathrm{~m}$ core was collected from $1.3 \mathrm{~m}$ of water using the Livingstone and Cobra corers. The stratigraphy is presented in Figure 5.

The lithology was highly variable with numerous very sharp transitions. Diatoms were dissolved but abundant at 256-140 $\mathrm{cm}$ and 70-60 $\mathrm{cm}$ depth and were present in all levels analysed. Diatom assemblage composition was variable, being dominated by dissolved centres of the robust diatoms, Campylodiscus clypeus and Amphora veneta in zones of poor preservation. In zones of higher quality preservation the most abundant taxa varied between subsamples, between C. clypeus, A. veneta and additional taxa such as Anomoeoneis sphaerophora, Cyclotella meneghiniana, Fragilaria fasciculata and Chaetoceros sp. resting spores. Other organic remains were also wellpreserved. An increase in abundance of ostracods and plant macrofossils above ca. $260 \mathrm{~cm}$ coincided with increased diatom abundance and a change to marl-rich clay. Ostracods, aquatic molluscs and charophytes were very abundant above $156 \mathrm{~cm}$. Charcoal was present throughout.

\section{Laguna del Taraje, Las Cabezas, Sevilla [CTRJ]}

A $1.37 \mathrm{~m}$ core was collected from $1.6 \mathrm{~m}$ of water using the Livingstone corer. The sediments were difficult to core further. The stratigraphy is presented in Figure 6 .

A major transition occurred at $112 \mathrm{~cm}$ depth from hard, homogeneous basal clays to more variable and organic-rich sediment above. Diatoms were preserved in the surface sediment, hut not at $5 \mathrm{~cm}$ and below. Ostracods were abundant and diverse in unconsolidated silty clay towards the core top but poorly preserved (fragmented and sparse) below $16 \mathrm{~cm}$. In general, preservation in the basal clays was poor compared to levels above $112 \mathrm{~cm}$. Above $112 \mathrm{~cm}$, aquatic seeds and molluscs were abundant, especially in an organic layer at 79$97 \mathrm{~cm}$. Charcoal was present throughout and most abundant above $60 \mathrm{~cm}$.

5, 6. Lagunas de Arjona [CARJ] and de la Alcaparrosa [CALC] Utrera, Sevilla.

Cores of $2.00 \mathrm{~m}$ and $1.80 \mathrm{~m}$ depth were collected in $0.60 \mathrm{~m}$ and $0.63 \mathrm{~m}$ of water in Lagunas de Arjona and de la Alcaparosa respectively, using the Livingstone and Cobra corers. The base of both reached limestone bedrock.

A partial assessment was made for the Laguna de Alcaparrosa only. Diatoms were rare at $10 \mathrm{~cm}$ below the surface and absent from lower levels. From the initial lithostratigraphic description, sediment at the core-base was a friable 'soily' matrix with large limestone inclusions (180-172 cm), compact dark grey clay with limestone and occasional molluscs (172-80 $\mathrm{cm})$ and soft grey-brown silty clay with abundant remaıns of Phragmites $(80-0 \mathrm{~cm})$.

\section{Laguna de Zarracatin, Utrera, Sevilla [CZRR]}

A $5.00 \mathrm{~m}$ core collected from below the salt crust of this hypersaline lake with the Cobra corer did not reach the natural substrate. The stratigraphy is presented in Figure 7.

The sediments were homogeneous clay or silty clay in which the main stratigraphic transitions were in colour and compaction. Rare diatom fragments were preserved at $170 \mathrm{~cm}$ depth in organic clays. Major phases of limnological change are indicated by the coincidence of high abundances of ostracods, aquatic molluses and charophytes around $350 \mathrm{~cm}$ and $175 \mathrm{~cm}$. A shift in ostracod species composition occurred at ca. $200 \mathrm{~cm}$ from dominance by Candona and Ilyocypris spp. to Eucypris mareotica; aquatic seeds were rare.

\section{Laguna Grande, Archidona, Malaga [BGDE]}

A $2.83 \mathrm{~m}$ core was collected from the centre of this permanent lake in $7 \mathrm{~m}$ of water using the Livingstone corer. The sediments were difficult to core owing to alternations between very soft silty clay or marly clay and hard salt bands; a longer corc could not be extracted.

Diatoms were fully-preselved from the surface to $80 \mathrm{~cm}$ depth and abundant but dissolved to $150 \mathrm{~cm}$ depth. They were occasional or rare below this level to the core base. Above 150 $\mathrm{cm}$ depth subsamples were dominated by Cyclotella distnguenda and Mastogloia smithii var. lacustwis. Dissolved valves of Campylodiscus clypeus characterised the lower core. The analysis was not pursued (see Discussion).

\section{Laguna Amarga, Lucena, Córdoba [AAMA]}

A $3.38 \mathrm{~m}$ core was collected from this permanent lake in 2.5 $\mathrm{m}$ of water using the Livingstone and Hiller corers. The stratigraphy is presented in Figure 8.

Basal sediments were hard silty clay rich in precipitated salt crystals, past which it would be difficult to core. The lithology was highly variable and alternated between clay, marly clay and gypsum bands of variable thickness. Diatom preservation was poor; occasional dissolved fragments were found in marly clays at the core base $(335-319 \mathrm{~cm}$ depth) and in two narrow organic-rich bands at $165 \mathrm{~cm}$ and $140 \mathrm{~cm}$. A major limnological transition at around $150 \mathrm{~cm}$ was indicated by the pool- preservation of organic remains below. Ostracod abundance increased progressively above $150 \mathrm{~cm}$ to the corc top. Ostracods were not identificdto species level. No molluscs 

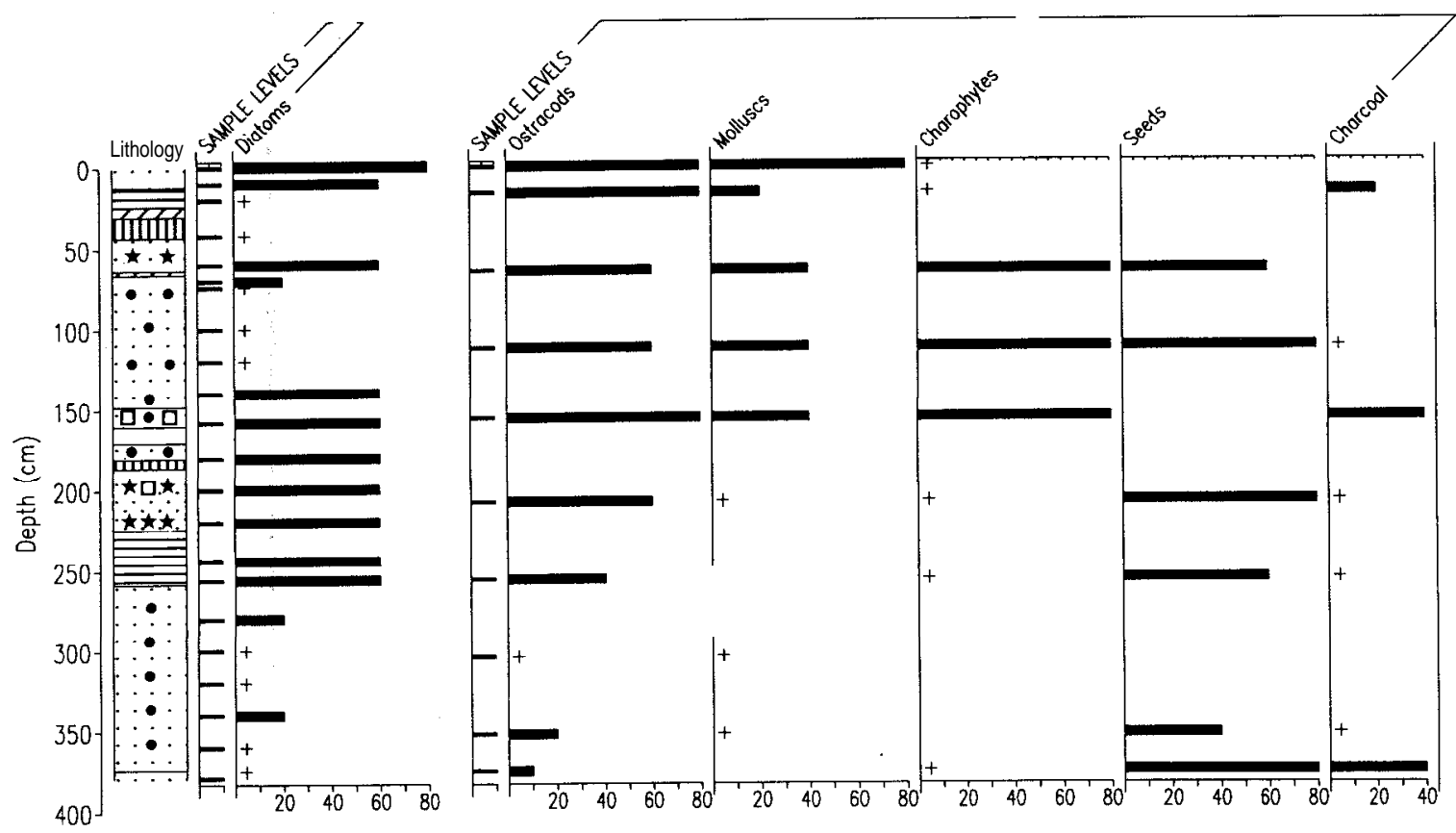

FIGURE 5. Stratigraphy of the Laguna Dulce, Espera, Cádiz FIGURA 5. Estratigrafía de la Laguna Dulce, Espera, Cádiz.
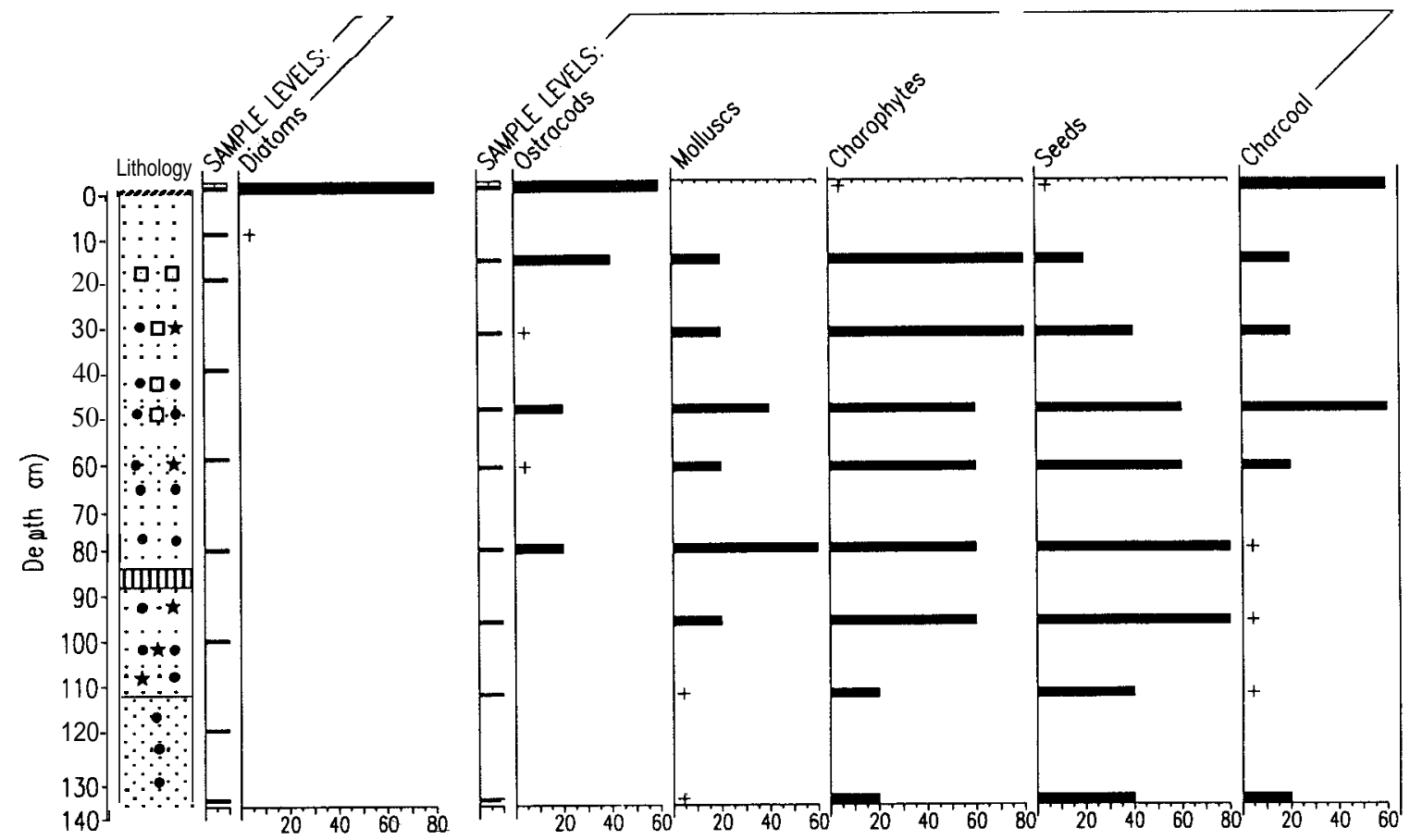

FIGURE 6. Stratigraphy of the Laguna del Taraje, Las Cabezas, Sevilla FIGURA 6. Estratigrafia de la Laguna del Taraje, Las Cabezas, Sevilla. 
were found. Charcoal was relatively abundant throughout

\section{El Salobral, Luque, Córdoba [ASBL]}

A $6.00 \mathrm{~m}$ core was collected from this ephemeral lake in 0.5 $\mathrm{m}$ of water using the Cobra corel. Basal sediments were still soft. The stratigraphy is presented in Figure 9.

Below the surface, dissolved diatom assemblages were preserved in only two samples, at $400 \mathrm{~cm}$ and $450 \mathrm{~cm}$. Ostracods, charophyte oospores and aquatic seeds were relatively abundant above $50 \mathrm{~cm}$, but were poorly-preselved below. Charcoal was abundant towards the surface and present at the core base.

\section{Laguna de Fuentillejo, Ciudad Real [EFTL]}

A $7.50 \mathrm{~m}$ core was collected from the dry lake-bcd of this steep-sided crater lake using the Cobra corer. The sediments were homogeneous sandy silty clay throughout, with some variability in colour, hardness and in the content of volcanic pebbles and sand. No diatoms or other palaeoecological remains were preserved.

\section{DISCUSSION}

\section{Diatom preservation}

As in the preliminary survey of sediment cores from ephemeral lakes in other regions of Spain which was alluded to above, the absence or very poor preservation of diatoms in two ephemeral lakes included in this survey (El Salobral and the Laguna de Fuentillejo) and one semi-permanent hypersaline lake (the Laguna de Zarracatin) again suggests the low potential of these types of lake in Spain for Holocene diatombased research. The other ephemeral lake included in this study, the Laguna de los Tollos, is an exception, since the preservation of diatoms at depth probably reflects its former permanence prior to drainage (FUREST \& TOJA, 1984).

Spanish salt lakes are small and shallow compared to those of many other saline lake regions (HAMMER, 1986), and the Iow quality of diatom preservation in many lake sediment records is probably related to their ephemeral character. This is certainly the case in the recent sediment record, where the most important factors affecting preservation are the physical and chemical effects of lake desiccation (REED, in press, a). In ephemeral lakes, increased water turbidity as the lake levels drop, followed by the drying out of the lake bed sediment, causes the physical breakage of frustules, often under conditions of high salinity which enhances dissolution. Their failure to be incorporated into the lake sediment record may also be exacerbated by the removal of dry surface sediments through wind deflation. In regard to the quality ot preservation over a longer timescale, it is possible that in Spain these lakes have always been ephemeral, and that their cullcnt ephemerality is generally a reliable predictor of their low potential for Holocene diatom analysis.

That the ephemerality of a lake in the modern environment is not always a good indicator of its past status and palaeoecological potential can be illustrated by reference to other saline lake regions. In the Konya Basin, central Turkey, for example, there are numerous ephemeral or dry lake basins which are vestiges of a large shallow (<10 m depth) Pleistocene lake, Lake Konya, and cores from some of these basins exhibit excellent diatom preservation at depth (ROBERTS, 1980; REED et al., submitted). The high quality of diatom preservation in this case is explained at least in part by the relatively low salinity $\left(<5 \mathrm{~g} \mathrm{l}^{-1}\right)$ and permanent character of the waters in the past, since other phases of these sediment records in which diatoms are poorly preserved are associated with periods of inferred high salinity and low lake levels (REED et al., submitted).

In addition to the Laguna de los Tollos, diatoms are also relatively well-preserved in the Laguna Dulce, in the Laguna Grande and at depth in the Laguna de Medina. Their poor preservation in the permanent Laguna Amarga and semi-permanent Laguna de Taraje, where desiccation effects are unlikely to account for dissolution, underlines the complicated nature of diatom dissolution, which in this case may have been enhanced by additional factors such as high $\mathrm{pH}$ or low sediment accumulation rate (FLOWER, 1993).

\section{Potential for Holocene palaeoclimate analysis}

From the results of the survey, five of the lakes surveyed in Cádiz and Sevilla in wester Andalucia (del Taraje. de Zarracatin, Dulce, de Medina and de los Tollos) would provide the ideal basis for the first regional palaeolimnological study of Holocene climate change in southern Spain. As noted, the Laguna Dulce, Espera (DDUL), the Laguna de Medina (DMDN) and the Laguna de los Tollos (DTLL) all exhibited relatively good diatom preservation at depth, and ostracods and other remains were abundant, whilst the sediments of other lakes nearby (the Laguna del Taraje [CTRJ] and Laguna de Zarracatin $[\mathrm{CZRR}]$ ) show the potential for complementary ostracod and mineralogical or geochemical analyses. In regard to other lakes surveyed. the two sites of Córdoba, central Andalucía (the Laguna Amarga, AAMA and El Salobral, ASBL) are located outside this tight cluster of lakes and do nor preserve diatoms, but could contribute to a regional data-set 
from the study of other proxy indicators (primarily ostracods. mineralogy and geochemistry in the Laguna Amarga, and mineralogy and geochemistry in El Salobral).

Apart from the Lagunas de la Alcaparrosa and de Arjona, which do not contain long sediment records, two lakes were of little potential value. The crater lake, Laguna de Fuentillejo, was exceptionally sterile and does not even preserve pollen (Tony Stevenson, pers. com.). The Laguna Grande, Archidona, Málaga was difficult to core. This is the only lake in the study to have been investigated previously; cores of approximately $3 \mathrm{~m}$ depth were collected for pollen analysis (WATTS, unpublislled data, BIRKS, unpublished data), but the same problems in coring were encountered and the record is unlikely to cover the earlier stages of the Holocene.

It is not the purpose of this paper to attempt a preliminary interpretation of climate change. Even on the limited data presented here, however, changes in lake level which may be related to climate change are indicated by shifts in species composition. The true planktonic diatom Ciclotella choctawhatcheeana, for example, occurred in phases of the Laguna de Medina and de los Tollos sequences. This is a strong indicator of higher lake levels than phases wherein assemblages are dominated by benthic or facultative planktonic diatoms, which arc more characteristic of the littoral zone. Shifts in diatom species composition would also indicate changes in lake water salinity, which can bc related to

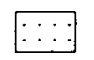

soft clay or silty clay

$\because \quad$ hard clay or silty clay

IIIIIII abundant reduced organics

QDA gypsum band

E laminated sediment

norecovery
- lenticular gypsum crystals*

aggregate gypsum crystals

prismatic gypsum crystals

tufa (precipitated on Chara stems)

sharp transition

very sharp transition

*Gypsum 5-point scale: Very abundant $=$ gypsum band Abundant-Occasional-Rare-(Niljndicatedas 3-2-1-10) crystal symbols

b) Key to palaeoecological abundance scales (related to wet sediment weight)*

\begin{tabular}{|cccccc|}
\hline TILIA SCALE & DIATOMS & OSTRACODS & MOLLUSCS & $\begin{array}{c}\text { Chara } \\
\text { OOSPORES }\end{array}$ & SEEDS \\
\hline 80 & Very abund. & Very abund & Very abund. & Very abund. & Very abund. \\
& undissolved & $>500 / \mathrm{g}$ & $>20 / 10 \mathrm{~g}$ & $>100 / \mathrm{g}$ & $>15 / 10 \mathrm{~g}$ \\
60 & Abundant & Abundant & Abundant & Abundant & Abundant \\
& dissolved & $150-500 / \mathrm{g}$ & $11-20 / 10 \mathrm{~g}$ & $10-100 / \mathrm{g}$ & $6-15 / 10 \mathrm{~g}$ \\
40 & - & Frequent & Frequent & - & Frequent \\
& & $50-150 / \mathrm{g}$ & $5-10 / 10 \mathrm{~g}$ & & $3-5 / 10 \mathrm{~g}$ \\
20 & Occasional & Occasional & Occasional & Occasional & Occasional \\
& dissolved & $5-50 / \mathrm{g}$ & $1-4 / 10 \mathrm{~g}$ & $<10 / \mathrm{g}$ & $1-2 / 10 \mathrm{~g}$ \\
& Rare fragments & Rare & Rare & Rare & Rare \\
& & $<5 / \mathrm{g}$ & $<\mathbf{1 / 1 0 \mathrm { g }}$ & $1-2$ tolal & $<1 / 10 \mathrm{~g}$ \\
\hline
\end{tabular}

*Relative abundance of charcoal estimated on a 5-point scale without quantification: Abundant (60), frequent (40), occasional (20). rare $(+)$, nil on the TILIA scale.
FIGURE 2. Key to

(a) lithostratigraphic and

(b) biostratigraphic descriptions.

FIGURA 2. Chve de descripción para

(a) lito-estratigrafía y

(b) bio-estratigrafía. 
lake level and climate change. In all cases the diatom records are characterised by taxa typical of oligosaline $\left(0.5-5 \mathrm{~g} \mathrm{l}^{1}\right)$ or mesosaline $\left(5-20 \mathrm{~g}^{1}\right)$ rather than fresh waters, and the shifts are too subtle to be interpleted without more detailed analysis. All the dominant taxa in the Laguna Dulce, for exalnple, tend to occur in mesosaline waters. The rapid shifts in species composition indicate marked limnological change, however, and it is possible that phases dominated by dissolved Campylodiscus clypeus, which is very resistant to dissolution, are related to periods during which lake levels were very low and other diatoms have not been preserved. The clearest change occurred in the Laguna Grande, where a shift from assemblages dominated by C. clypeus in the lower sequence to Cyclotella distinguenda and Mastogloia smithii var. Lacustris in the upper sequence represents a lowering of salinity and probable increase in lake leves although, as noted the core is unlikely to cover a long time period and the change is most likely related to human impact rather than climate change.

Most ostracods and other palaeoecological indicators have not been identified to species level in this study, but would provide valuable complementary data. The change in dominance from Plesiocypridopsis newtoni to Cyprideis torosa in the Lagunas Medina and de los Tollos, for example, can be related to a shift from relative ephemerality to permanence (DE DECKKER, 1998). In regard to mineralogy, changes in the abundance and character of gypsum crystals (lenticular versus prismatic) may be related to their being precipitated from the open water (deeper lake-level stage) or from within the sediment (shallower lake-level stage) (CODY \& CODY, 1988), whilst shifts between laminated sediments and sediments dominated by massive lenticular gypsum can be related to permanent versus ephemeral waters (HARDIE et al., 1978).

In addition, there is a large body of data from ongoing neolimnological work throughout Spain which can provide excellent 'modern analogues' for interpretation of the data.
Apart from individual studies (e.g. UBIERNA LEON \& SANCHEZ CASTILLO, 1992, for diatoms) large data-sets of species and ecological data are now available for both diatoms (REED, in press, b. from Spain, and GASSE et al., 1995 from neighbouring Africa) and ostracods (BALTANAS. 1992. BALTANAS et al., 1990).

Thus, there is ample scope for a comprehensive regional survey. This potential has been borne out by a detailed palaeoenvironmental study of the Holocene record of one of these lakes, the Laguna de Medina, using diatom, ostracod, mollusc and plant macrofossil palaeoecological techniques, mineralogy and pollen analysis (REED, 1995, REED \& STEVENSON, in prep.). This has produced the first evidence for mid-Holocene variation in climate in southern Spain. and includes an abrupt arid interval after ca 7,800 years BP which is in line with similar evidence from lakes of the northern Sahara. Holocene palaeolimnological research is also being carried out by B. Davis, A.C. Stevenson and colleagues at Newcastle University, UK, on other saline lakes of Andaluci'a and other parts of Spain, under the aegis of the ENCINAS Project (results forthcoming).

\section{ACKNOWLEDGEMENTS}

This research was funded as part of a NERC Framework PhD Award supervised by Rick Battarbee (University College London), Steve Juggins and Tony Stevenson (Newcastle University), whose help during the project is gratefully acknowledged. Thanks also go to Catherine Pykc of UCL for assistance with the artwork and to the many colleagues who helped with fieldwork. The work would not have been possible without the assistance of Prof. Carlos Montes and colleagues of the Universidad Autónoma, Madrid, who arranged access to the nature reserves of southern Spain. The help and keen interest shown by the Directors and nature reserve guards of the Medio Ambiente in Andalucia was also valued. 


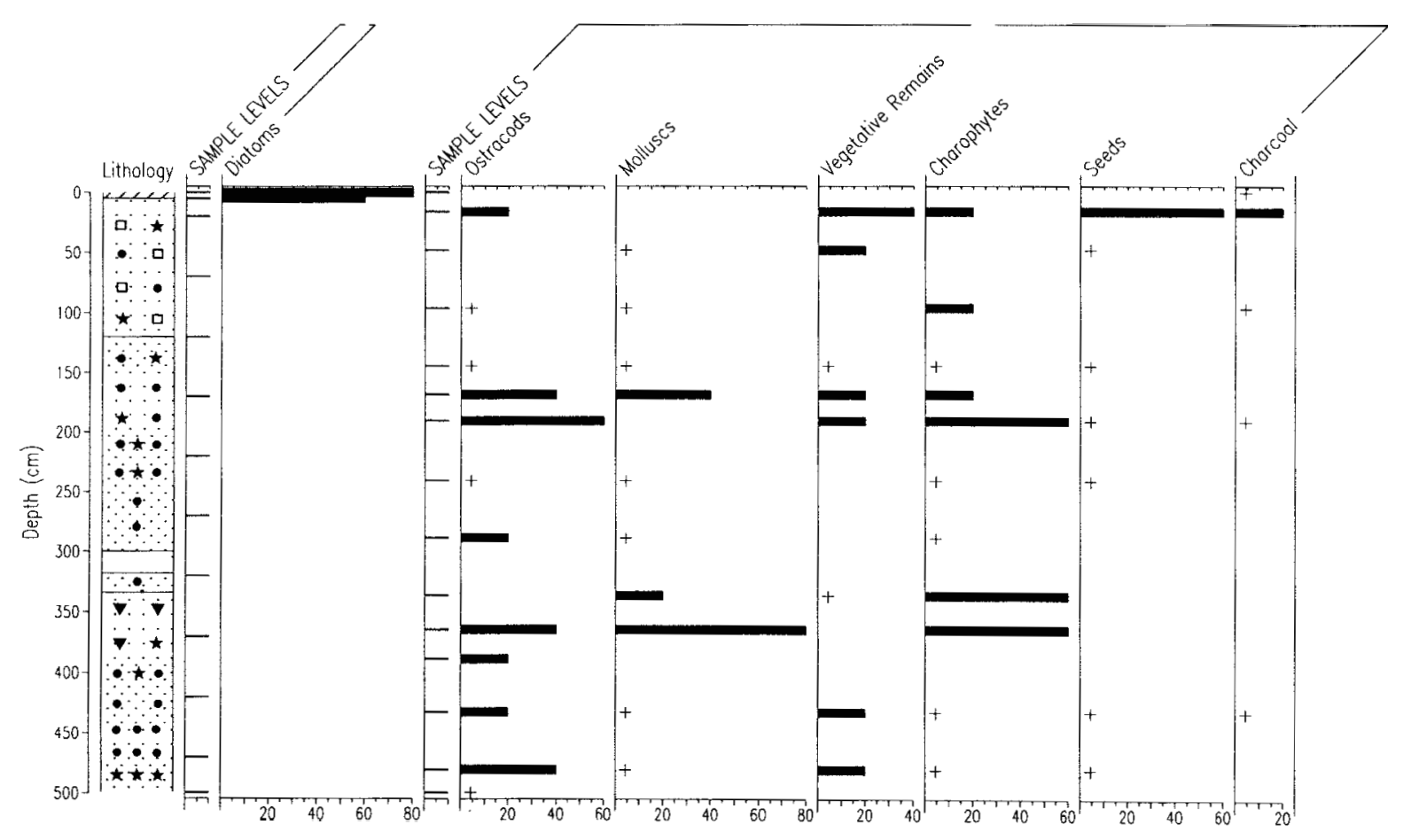

FIGURE 7. Stratigraphy of the Laguna de Zarracatín. Utrera, Sevilla. FIGURA 7. Estratigrafia de la Laguna de Zarracatín, Utrera, Sevilla.
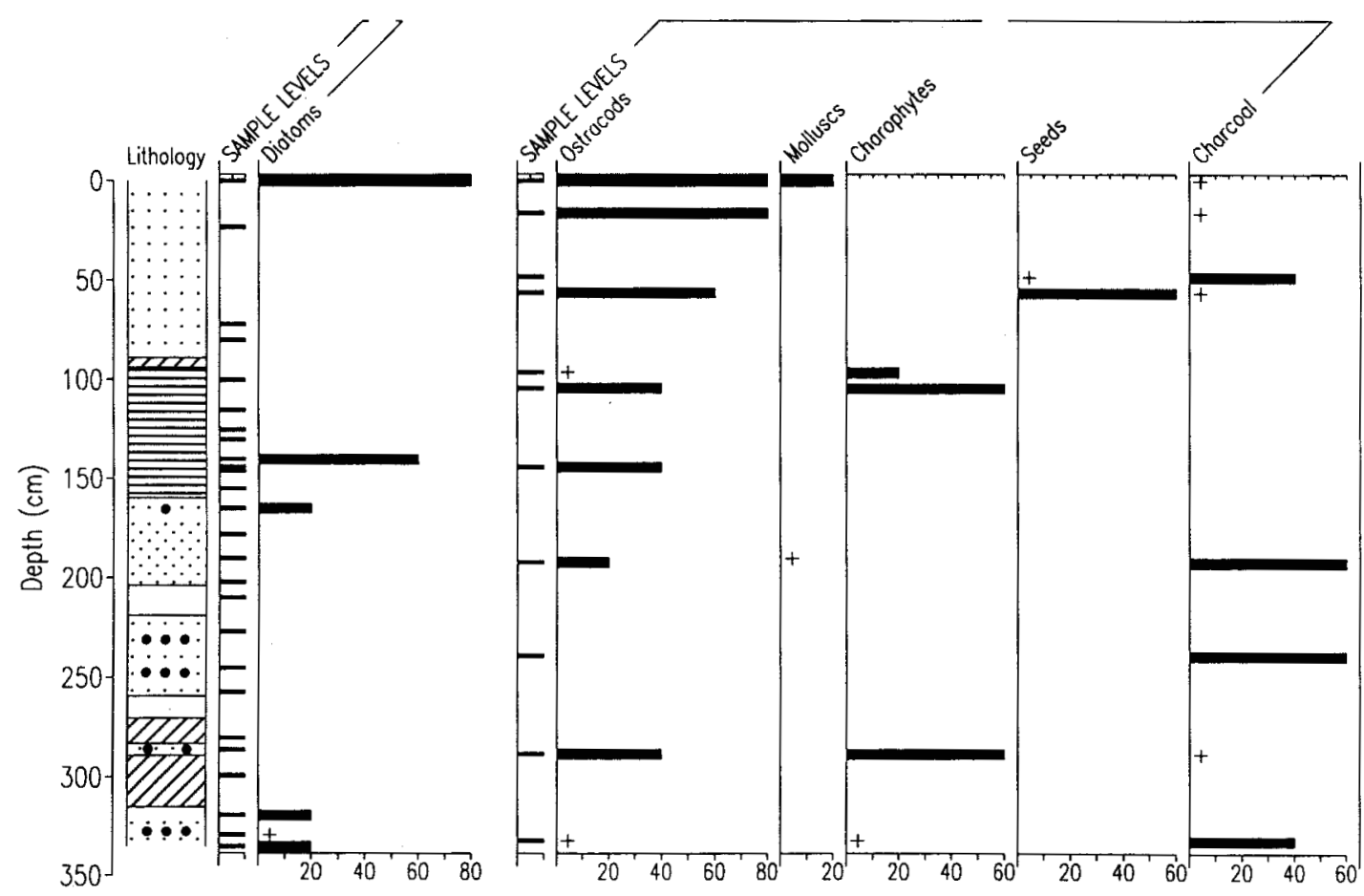

FIGURE 8. Stratigraphy of the Laguna Amarga, Lucena, Córdoba FIGURA 8. Estratigrafia de In Laguna Arnarga, Lucena, Cordoba. 

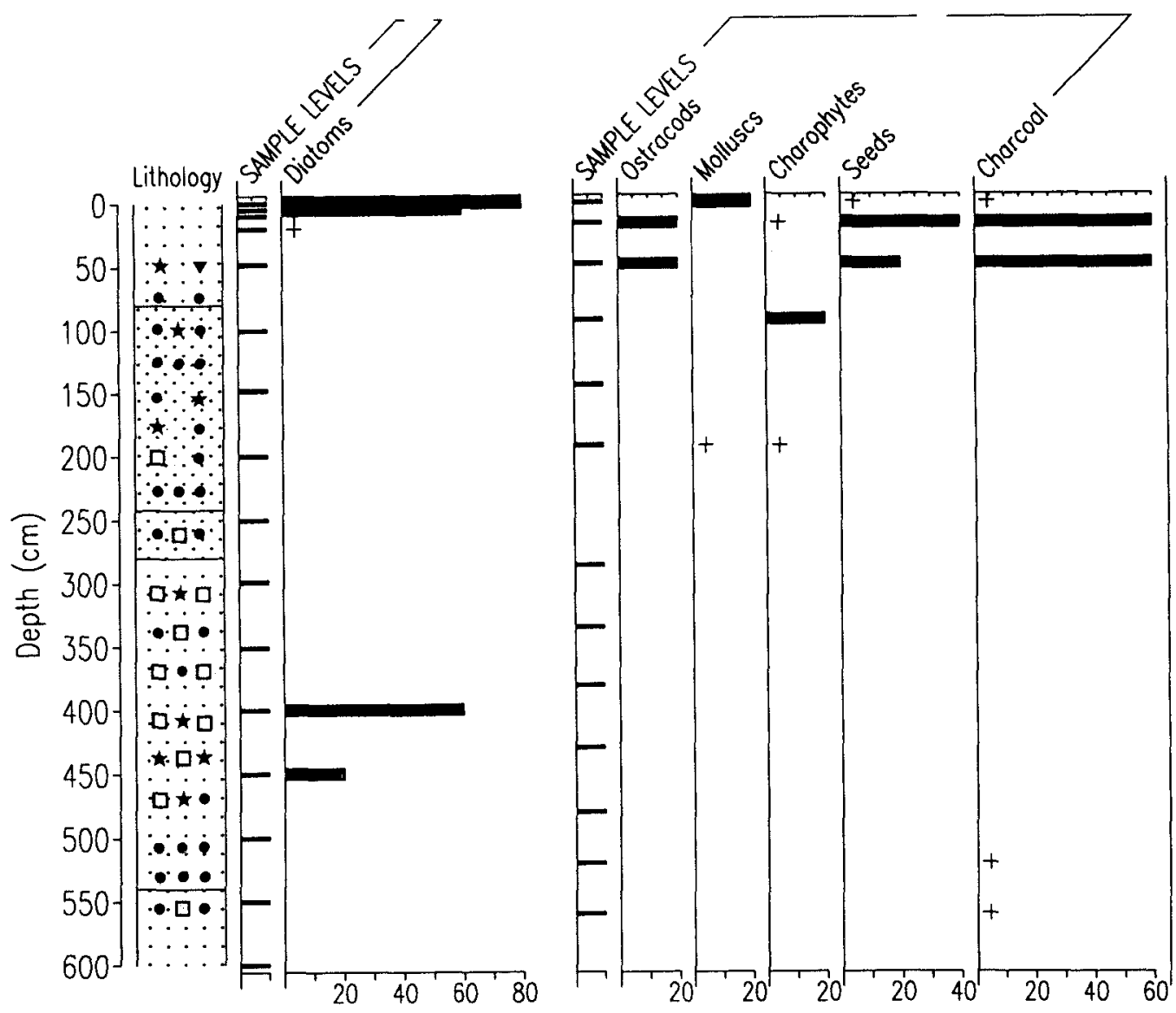

FIGURE 9. Stratigraphy of E Salobral, Luque, Córdoba FIGURA 9. Estratigrafía de El Salobral, Luque, Córdoba.

\section{REFERENCES}

AABY, B. \& BERGLUND, B.E., 1986. Characterization of peat and lake deposits. In Handbook of Holocene Palaeoecology and Palaeohydrology (ed. B.E. Berglund), pp. 231-246. John Wiley, Chichester.

BALTANAS, A., 1992. A contribution to the knowledge of the cypridid ostracode fauna (Crustacea, Ostracoda, Cyprididae) on the Iberian Peninsula, and a comparison with ad jacent areas. Arch. Hydrobiol./Suppl. 90: 419-452.

BALTANAS, A., MONTES, C. \& MARTINO, P., 1990. Distribution patterns of ostracods in iberian saline lakes. Influence of ecological factors. Hydrobiologia 197: 207-220.

BATTARBEE, R.W., 1986. Diatom Analysis. In Handbook of Holocene Palaeoecology and Palaeohydrology (ed. B. E. Berglund), pp. 527-570. John Wiley, Chichester.

BURILLO MOZOTA, F., M. GUTIÉRREZ ELORZA, J.L. PENA MONNE \& C. SANCHO MARCEN, 1986. Geomolphological processes as indicators of climatic changes during the Holocene in the north-east Spain. Quaternary Climate in Western Mediterranean (ed. F. LópezVera), pp. 31-44. Universidad Autónoma de Madrid, Madrid.

CODY, R.D. \& CODY, A.M., 1988. Gypsum nucleation and crystal morphology in analog saline terrestrial environments. J. Sedimentary Petrology 58: 247-255.

COMÍN, F.A., JULÍA, R., COMÍN, M.P. \& PLANA, F., 1990. Hydrogeochemistry of Lake Gallocanta (Aragón, NE Spain). Hydrobiología 197: 51-66.

COMÍN, F.A. \& ALONSO, M., 1988. Spanish salt lakes: Their chemistry and biota. Hydrobiologia 158: 237-245. 
DAVIS, B.A.S., 1994. Palaeolimnology and Holocene Environmental Change from Endoreic Lakes in the Ebro Basin, North-East Spain. PhD thesis, University of Newcastle.

DE DECKKER, P., 1988. Biological and sedimentary facies of Australian salt lakes. Palaeogeography, Palaeoclimatology, Palaeoecology 62: 463-475.

DE DECKKER, P. \& R.M. FORESTER, 1988. The use of ostracods to reconstruct continental palaeoenvironmental records. In Ostracoda in the Earth Sciences (eds. P. De Deckker, J-P. Colin \& J-P. Peypouquet), pp. 175-199. Elsevier, Amsterdam.

DE TERÁN, M, SOLE SABARIS, L. et al. (eds.), 1978. Geografía Regional de España. Editoral Ariel, Barcelona, Spain. $491 \mathrm{pp}$.

DUPRE, M., M.P. FUMANAL, E. SANJAUME, C. SANTISTEBAN, J. USERA \& M.J. VIÑALS, 1988. Quaternary evolution of the Pego Coastal lagoon (southern Valencia, Spain). Palaeogeography, Palaeoclimatology, Palaeoecology 68: 291-299.

FERNANDEZ-PALACIOS, J.M., 1990. Lagunas de Cádiz (Medina y Salada). In Humedales Españoles en la Lista del Convenio de Ramsar (eds. A Troya Panduro y M. Bernués Sanz), pp. 9-24. Ministerio de Agricultura, Pesca y Alimentación. Instituto Nacional para la Conservación de la Naturaleza, Madrid, Spain.

FLOWER, R.J., 1993. Diatom preservation: experiments and observations on dissolution and breakage in modern and fossil material. Hydrobiologia 2691270: 473-484.

FONT TUllot, 1., 1983. Climatología de España y Portugal. Instituto Nacional de Meteorologia, Madrid.

FONT TUllot, I., 1988. Historia del Clima de España. Cambios climátcos y sus causas. Instituto Nacional de Meteorologia, Madrid.

FRITZ, S.C., D.R. ENGSTROM \& B.J. HASKELL, 1994. 'Little Ice Age' aridity in the North American Great Plains: a high-resolution reconstruction of salinity fluctuations from Devils Lake, North Dakota, USA. The Holocene 4: 69-73.

FUREST, A. \& TOJA, J., 1984. Reconocimiento Limnológico de Lagunas Andaluzas. In Lns Zonas Húmedas en Andalucía (ed. Agencia de Medio Ambiente). Monografias de la Dirección General de Medio Ambiente, Madrid.

GASSE, F., 1987. Diatoms for reconstructing palaeoenvironments and paleohydrology in tropical semi-arid zones. Hydrobiologia 154: 127-163.

GASSEb F., S. JUGGINS \& L. BEN KHELIFA, 1995. Diatom-based transfer functions for inferring past hydrochemical characteristics of African lakes. Palaeogeographys Palaeoclimatology, Palaeoecology 117: 31-54.

CASSE, F., J-C. FONTES, J.C. PLAZIAT, P. CARBONEL, I. KACZMARSKA, P. DE DECKKER, I. SOULIÉMARSCHE, Y. CALLOT \& P.A. DUPEUBLE. 1987. Biological remains, geochemistry and stable isotopes for the reconstruction of environmental and hydrological changes in the Holocene lakes from North Sahara. Palaeogeoglaphy Palaeoclimatology, Palaeoecology 60: 146.

GLEW, J.R., 1991. Miniature gravity corer for recovering short sediment cores. / Paleolim. 5: 285-287.

HAMMER, U.T., 1986. Saline Lake Ecosystems of the World. Dr. W. Junk Publrs, The Hague. 616 pp.

HARDIE, L.A., SMOOT, J.P. \& EUGSTER, H.P., 1978. Saline lakes and their deposits: a sedimentological approach. In Modern and Ancient Lake Sediments, Spec. Publn. Intl. Ass. Sediment. (eds. A. Matter \& M. E. Tucker), Vol. 2, pp. 741. Blackwell Scientific Publications, Oxford.

HUNTLEY, B. \& I.C. PRENTICE, 1988. July temperatures in Europe fiom pollen data, 6000 years before present. Science 241: 687-690.

JUNTA DE ANDALUCÍA, 1991. Plan Rector de Uso y Cestidn de las Rescrvas Natulales de las Lagunas dc Cádiz. Junta de Andalucía, Spain. 240 pp.

LIVINGSTONE, D.A., 1955. A lightwieght piston sampler for lake deposits. Ecology 36: 137-139.

MACKLIN, M.G.. D.G. PASSMORE, A.C. STEVENSON, B.A. DAVIS \& J.A. BENAVENTE, 1994. Responses of Rivers and Lakes to Holocene Environmental Change in the Alcañiz Region, Teruel, North-East Spain. In Environmental Change in Drylands: Biogeographical and Geomorphological Perspectives (eds. A.C. Millington \& K. Pye) pp. 113- 130. John Wiley, Chichester.

MARGALEF, R., 1947. Estudios sobre la vida en las aguas continentales de la regidn endorreica manchega. P. Inst. Biol. Apl. IV: 5-51.

MENENDEZ AMOR, J. \& F. FLORSCHUTZ, 1961. Contribución al conocimiento de la historia de la vegetacidn en España durante el Cuaternario. Estudios Geológicos 17: 83-99:"

MENENDEZ AMOR, J. \& F. FLORSCHUTZ, 1964. Results of the preliminary palynological investigation of samples from a $50 \mathrm{~m}$ boring in southern Spain. Bol. Real Soc. Española Hist. Nat. (Geol.) 62: 251-255.

MONTES, C. \& MARTINO, P., 1987. Las Lagunas Salinas Españolas. Real Academia de Ciencias Exactas, Fisicas y Naturales, Madrid. 
PARDO. L.. 1948. Catalógo de los lagos de España. Biología de las aguas continentales. ed., Vol. VI, Inst. For. Inv. Exp., $522 \mathrm{pp}$.

REED, J.M.. 1995. The potential of diatoms and other palaeolimnological indicators for Holocene palaeoclimate reconstruction from Spaslish salt lakes, with special, reference to the Laguna de Medisla (Cádiz, southwest Spain). PhD thesis, University College London, London.

REED. J.M. (in press a). Diatom preservation in the recent sediment record of Spanish salt lakes: implications for palaeoclimate study. J. Paleolim.

REED, J.M. (in press b). A diatom-conductivity transfer function for Spanish salt lakes. J. Paleolim.

REED, J.M., ROBERTS, C.N. \& LENG, M.J. (submitted). Late Quaternary palaeolimnological and climate change in two lakes of contrasting hydrology in the Konya Basin, Turkey. Quatemary Science Reviews.

RIERA-MORA, S. \& A. ESTEBAN-AMAT, 1994. Vegetation history and human activity during the last 6000 years on the central Catalan coast (northeastern Iberian Peninsula). Vegetation History and Archueobotany 3: 7-23.

ROBERTS, C. N.. 1980. Late Quatenary Geomorphology and Palaeoecology of the Konya Basin, Turkey. PhD thesis, University College London. London.
RYVES, D.B., 1994. Diatom dissolution in saline lake sediments. An experimental study in the Great Plains of North America. PhD thesis, University College London. London.

SILJESTROM, P.A., MORENO, A. GARCÍA. L.V. \& CLEMENTE, L.E., 1994. Doñana National Park (southwest Spain): geomorphological characterization through a soil-vegetation study. J. of Arid Environments 26: 315-323.

STEVENSON, A.C. \& R.J. HARRISON. 1992. Ancient Forests in Spain: A Model for Land-use and Dry Forest Management in South-west Spain from 4000 BC to 1900 AD Proceedings of the Prehistoric Society 58: 227-247.

STEVENSON, A.C., M.G. MACKLIN, D.G. PASSMORE \& J.A. BENAVENTE, 1991. Respuesta de los sistemas lacustres y fluviales a los cambios medioambientales y a la actividad humana cn Alcañiz (Teruel). Al-Qannis 2: 25-35.

TERRAL, J-F \& ARNOLD-SIMARD, 1996. Beginnings of olive cultivation in Eastern Spain in relation to Holocene Bioclimatic Changes. Quaternary Research 46: 176-185.

UBIERNA LEÓN, M.A. \& SANCHEZ CASTILLO, P. M.. 1992. Diatomoflora de varias lagunas de apuas mineralizadas de las provincias de Málaga y Granada. Anales del Jardín Botánico de Madrid 49: 171 - 185. 